\title{
Ambiguous genitalia: clinical management of adult female with male assigned gender: a case report
}

Mahamudu Ayamba Ali ${ }^{1,2}$, Raymond Saa-Eru Maalman ${ }^{1}$, Yaw Otchere Donkor ${ }^{1 *}$ (D) and James Edward Mensah 3,4

\begin{abstract}
Background: Disorders of sex development are anomalies in which the development of urogenital ridge is undifferentiated for the male and female child. Imaging plays a vital role in investigating the gross anatomy and associated anomalies. Ultrasonography, such as genitography and magnetic resonance, is the primary modality for demonstrating internal gonads and genitalia. Early multidisciplinary approach in the management of ambiguous genitalia including early surgical intervention is the predominant practice, with few current considerations on deferral of genital reconstruction until adolescent age.

Case presentation: We report the rare case of a 24-year-old adult female from a majority ethnic group of the Volta region, Ghana who was diagnosed and raised as male, now requiring surgical restoration to the female gender. The surgical team decided to assign external genitalia to correspond with the already intact internal organs, thus constructing the vulva. Consent was given by the client and her family members for management and surgical intervention. The surgery was scheduled and duly performed with a successful outcome. Understanding and consent was sought from the patient for the purpose of using her images for teaching, scientific publication, and demonstrations.
\end{abstract}

Conclusion: The advantages of deferring surgical reconstruction with psychological counseling after early assessment need to be considered to prevent inappropriate gender assignment.

Keywords: Disorders of sex development, Ambiguous genitalia, Clinical management, Surgical approach, Adult female

\section{Background}

The term ambiguous genitalia describes the most common clinical presentation of a variety of congenital conditions classified as disorders of sexual development (DSD) or differences in sex development [1, 2]. DSDs are associated with atypical development of the internal and external genital structures as a result of variations in genes, developmental programming, and hormones [3]. DSDs occur when chromosomal, gonadal, or anatomical

*Correspondence: dotchere@uhas.edu.gh

${ }^{1}$ Department of Basic Medical Sciences, School of Medicine, University of Health and Allied Sciences, Ho, Volta Region, Ghana

Full list of author information is available at the end of the article sex is atypical [4,5], and before 2006, DSD was termed as intersex [2]. Based on the karyotype, three main groups of DSDs are identified using the new nomenclature proposed by the Chicago Consensus (Table 1).

Disorders of sex development are a major pediatric issue, accounting for approximately $1 \%$ of all live births [5]. However, the incidence varies between developed and developing countries [6]. In Ghana, there is a paucity of information, but in other developing countries such as Saudi Arabia incidence is reported as 1 in 2500 live births and in Egypt 1 in 3000 live births $[2,6]$. In a developed country such as Germany, the incidence is as low as 2 per 10,000 live births. The high rate of DSD was hypothesized to result from higher consanguinity original author(s) and the source, provide a link to the Creative Commons licence, and indicate if changes were made. The images or other third party material in this article are included in the article's Creative Commons licence, unless indicated otherwise in a credit line to the material. If material is not included in the article's Creative Commons licence and your intended use is not permitted by statutory regulation or exceeds the permitted use, you will need to obtain permission directly from the copyright holder. To view a copy of this licence, visit http://creativecommons.org/licenses/by/4.0/. The Creative Commons Public Domain Dedication waiver (http://creativeco mmons.org/publicdomain/zero/1.0/) applies to the data made available in this article, unless otherwise stated in a credit line to the data. 
Table 1 Disorders of sex development: Chicago Classification of sex [4]

\begin{tabular}{|c|c|c|}
\hline Sex chromosome DSD & $46, X Y$ DSD & $46, X X$ DSD \\
\hline 45, XO (Turner syndrome and variants) & $\begin{array}{l}\text { Disorders of gonadal (testicular) development } \\
\text { Complete gonadal dysgenesis (Sawyer syndrome) } \\
\text { Partial gonadal dysgenesis, gonadal regression, ovotesticu- } \\
\text { lar DSD }\end{array}$ & $\begin{array}{l}\text { Disorders of gonadal (ovarian) development } \\
\text { Ovotesticular DSD } \\
\text { Testicular DSD (SRY+, dup SOX9) } \\
\text { - Gonadal dysgenesis }\end{array}$ \\
\hline 47, XXY (Klinefelter syndrome and variants) & $\begin{array}{l}\text { Disorders in androgen synthesis or action • Androgen } \\
\text { biosynthesis defect (17-hydroxysteroid dehydrogenase } \\
\text { deficiency, } 5 \text { a-reductase deficiency) }\end{array}$ & $\begin{array}{l}\text { Androgen excess } \\
\text { Fetal (21-or 11-hydroxylase deficiency) }\end{array}$ \\
\hline $\begin{array}{l}45, X / 46, X Y \text { (mixed gonadal dysgenesis, } \\
\text { ovotesticular DSD) }\end{array}$ & $\begin{array}{l}\text { Defect in androgen action (complete androgen insensitivity } \\
\text { syndrome) }\end{array}$ & $\begin{array}{l}\text { Fetoplacental (aromatase deficiency, P450 } \\
\text { oxidoreductase) }\end{array}$ \\
\hline 46, XX/46, XY (chimeric, ovotesticular DSD) & $\begin{array}{l}\text { LH receptor defects (Leydig cell hypoplasia) } \\
\text { Disorders of AMH and AMH receptor (persistent Müllerian } \\
\text { duct syndrome) }\end{array}$ & Maternal (luteoma, exogenous) \\
\hline
\end{tabular}

DSD: Disorders of Sex development, LH: Luthenizing hormone, AMH: Antimulerian hormone, SRY: Sex region Y chromosome

among populations of developing countries than among those from developed countries [2]. The underlying cause of ambiguous genitalia in a newborn/child needs extensive and urgent investigation to avoid missing a life-threatening problem such as congenital adrenal hyperplasia $(\mathrm{CAH})$, which is a major presentation of DSD [2].

Clinical management of DSDs is carried out per the classification proposed by the Paediatric Endocrinology Society Lawson Wilkins and the European Society of Paediatric Endocrinology [7]. The management of patients with DSD and related conditions is focused on four aspects: (1) etiological diagnosis, (2) assignment of gender, (3) indication for and timing of genital surgery, and (4) disclosure of medical information to the patient [8]. Thorough clinical, hormonal, radiological, chromosomal, and molecular evaluations are therefore essential. However, a prompt evaluation of these assignments may be challenging for accurate diagnosis and appropriate therapy, especially in resourcedeprived countries. Satisfactory management of these children does not merely demand early diagnosis and appropriate treatment, but gender assignment will produce a positive impact on the outcome. Failure of the appropriate approach causes great discomfort for family and healthcare providers [9].

Genetic tools such as microarray analyses and nextgeneration sequencing techniques have identified novel genetic variants among patients with DSD. Most importantly, patient management needs to be individualized especially for decisions related to the sex of rearing, surgical interventions, hormone treatment, and potential for fertility preservation [3]. In countries with an inadequate health system, there are challenges in the diagnosis as well as management of DSDs, as in the case reported herein.

\section{Case presentation}

A 24-year-old from a majority ethnicity of Volta region Ghana was referred on account of 7 years cyclical total painless hematuria, which lasted about 2-3 days per episode for the past 3 years. This was often preceded by mild lower abdominal pain and malaise. There was no identifiable risk factor for bladder carcinoma (habits or exposure). The patient is the eldest of five siblings, who are all alive and had normal pregnancy and delivery periods. The mother was on the routine antenatal medications as always prescribed in Ghana. Two of her siblings also had a similar genital appearance and were undergoing medical examinations. She was christened and raised as a male from infancy to adolescence when she noticed the development of female secondary sexual characteristics (breast, changes in voice, hair distribution pattern, and general hip enlargement). She stopped her education and migrated to the city where she has been residing since then. Physical examination reveals feminine figure appearance, well-developed breast, female hair distribution pattern, and a feminine voice. She had a mega clitoris without vaginal opening (Fig. 1), and the vagina or labial/scrotal area shows a solid perineal mass. The urethral opening was underneath the clitoris (Fig. 2).

\section{Management of the case}

The management of the DSD in this case was focused on first ascertaining the etiological diagnosis. This was done by performing an abdominopelvic ultrasound scan, which showed normal uterus and ovaries. Urethrocystoscopy demonstrated a normal bladder mucosa, ureteric orifices, and a poorly 


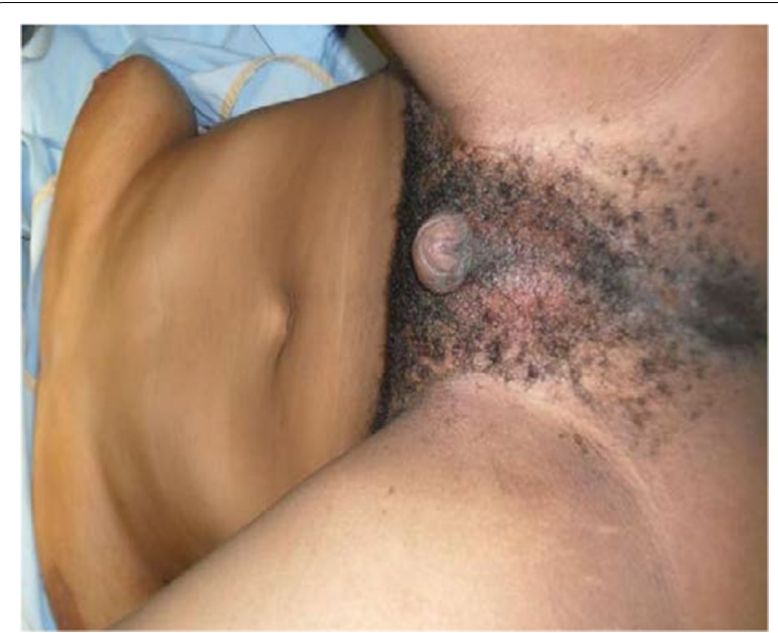

Fig. 1 A mega clitoris without vaginal opening

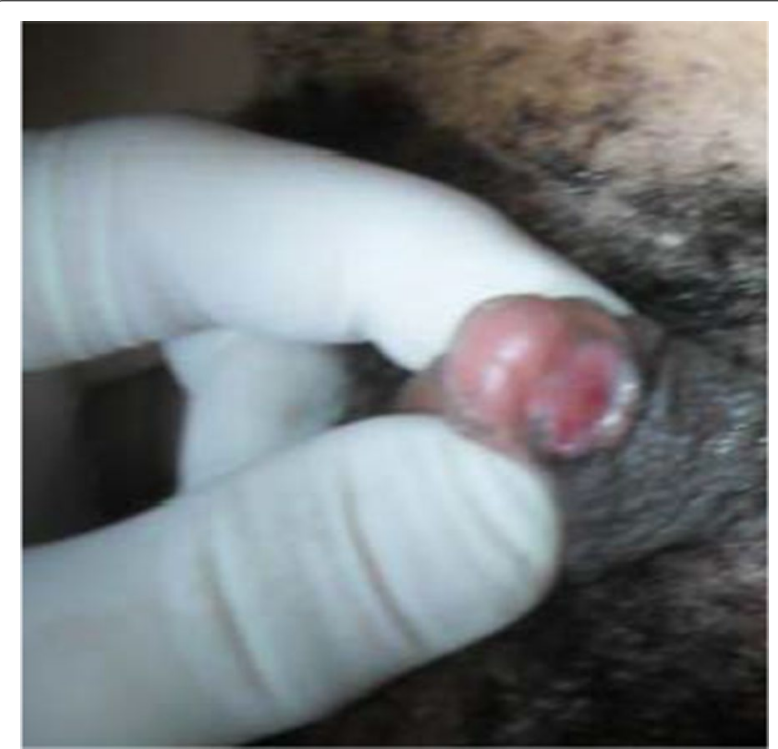

Fig. 2 Mega clitoris with hypospadias

visualized dimple in the urethral mucosa distal to the sphincter. A diagnosis of 46, XX DSD secondary to androgen excess was made (Table 1). Since all the internal female genital organs were found to be normal, the second decision of the surgical team was the assignment of the external genitalia to correspond with the internal organs; thus, construction of the vulva was indicated (Fig. 3). The client and her family were informed of the diagnosis and the treatment option arrived at by the team. Consent was given by the client and her family members in a signed form. The surgery was scheduled and duly performed with successful

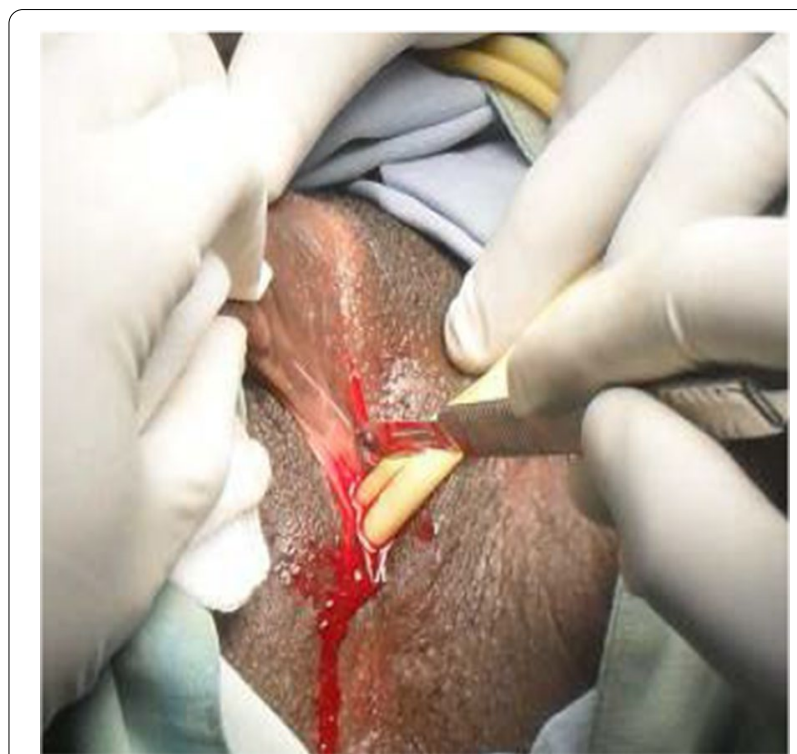

Fig. 3 Vaginal and urethral catheters during separation

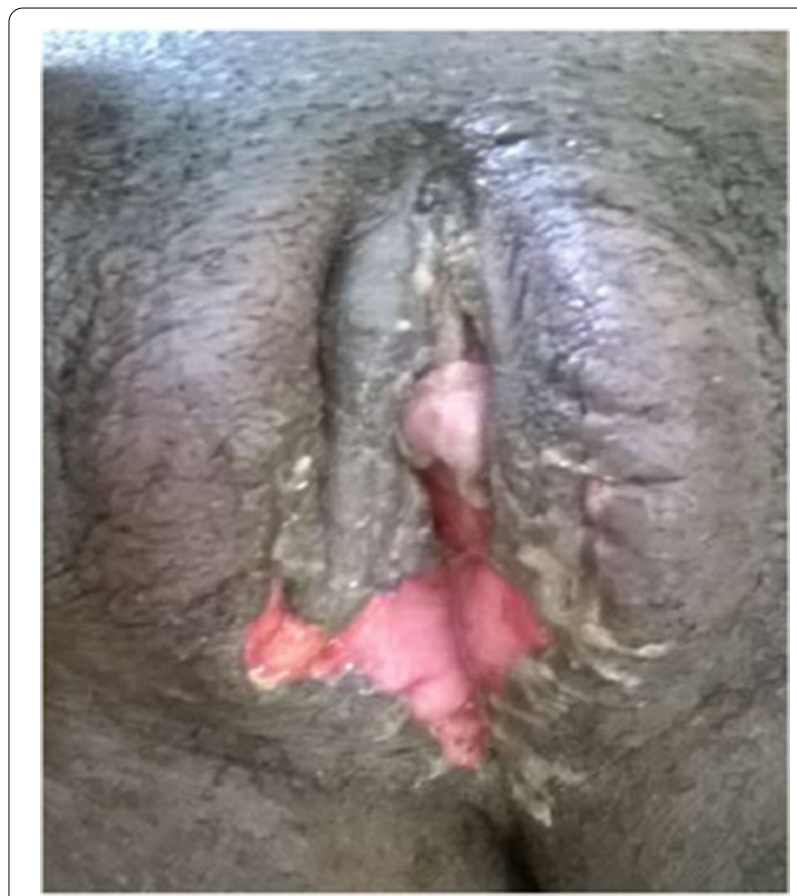

Fig. 4 Post vaginoplasty and neoclitoroplasty

separation, vaginoplasty, and neoclitoroplasty, as seen in Figs. 3 and 4. The patient's follow-ups and review after treatment were scheduled for monitoring of the aftermath of the surgery. Her review revealed that the procedure had been successful, with no adverse event. Understanding and consent were sought from the 
patient for the purposes of using her images for teaching, scientific publication, and demonstrations.

\section{Discussion}

The formation of a typical male or female sex organ involves numerous and complex genetic and physiological events such as sex determination during fertilization, development at the gonadal ridge, expression of the mesonephric or paramesonephric ducts, differentiation into internal and external organs during the zygotic phase, growth of these reproductive organs to phenotypic recognition, and masculinization or feminization from birth to puberty under the influence of hormones and transcription factors $[10,11]$.

Managing an adult with ambiguous external genitalia requiring surgical intervention is extremely rare as patients with various spectra of the disease requiring surgical intervention most probably would have received it during childhood or adolescence [12,13]. The current practice for managing these diseases is an early multidisciplinary approach that often includes early surgical evaluation and possible reconstruction, at most deferring until adolescence [14]. The early approach in assigning gender is influenced by the desire to limit identity crisis, which is believed to help reduce parental anxiety, satisfy some unique sex-related cultural practices, and above all, help in the sociocultural growth of the child [14].

Advocates for deferral of surgical intervention raise concern that the influence of high maternal estrogen levels that causes clitoromegaly could be mistaken for male phallus, leading to wrong gender assignment. Continuous psychological counseling while delaying vaginoplasty is currently considered. This approach is believed to allow for tissue growth that will make surgery relatively easy. Full patient participation in the evaluation and treatment, as in this case under review, is critical. The optimal timing of the surgery remains unclear. This case report has taught us many lessons associated with the timing of DSD management, including:

1. It confirms the difficulty associated with early biological sex determination among ambiguous genitalia neonates.

2. It lays out the social consequences of raising a child with a wrong gender, including predisposition to bullying and mockery by peers, withdrawal from school, need for relocation, and change of name and dressing style when the secondary sex organs become prominent.

3. It emphasizes the heightened anxiety of the patient and relatives over the delay in correction and the need for prolonging psychological counseling if a delay is contemplated.
4. There is an advantage to conducting a limited investigation (concentrating on the urogenital area and internal organs) since secondary sexual features have already developed and directed the biological gender, especially in hospitals with limited diagnostic abilities.

5. It demonstrates the relative ease of surgical intervention as a result of well-developed structures at the perineal area for dissection and raising of flaps during vaginoplasty and neoclitoroplasty.

6. It shows reduced postoperative complications in terms of infections and reconstructive breakdown.

7. It resulted in good functional outcome and patient satisfaction.

\section{Conclusion}

The advantages of deferring surgical reconstruction with psychological counseling after early assessment need to be considered to prevent inappropriate gender assignment.

\section{Abbreviations \\ DSDs: Disorders of sex development; CAH: Congenital adrenal hyperplasia. \\ Acknowledgements \\ Authors are grateful and duly acknowledge Margaret Marquart Catholic Hospital, Kpando, Ghana nurses, and all medical team for the opportunity and support. We are also thankful to the patient for having confidence in us for a successful outcome.}

\section{Authors' contributions}

All authors participated in the design of the study, acquired data, performed literature review, drafted the manuscript, and edited the manuscript. Dr. Ali Ayamba and Dr. James Mensah helped in the patient's management. All authors read and approved the final manuscript.

\section{Funding}

The authors have no funding to declare.

Availability of data and materials

The published information is available from the corresponding author on reasonable request.

\section{Declarations}

\section{Ethics approval and consent to participate}

This study was conducted in accordance with the fundamental principles of the Declaration of Helsinki. This is a retrospective report of a successful management of DSDs. Thus, ethical approval and consent to participate are not applicable.

\section{Consent for publication}

Written informed consent was obtained from the patient for the publication of this case report and any accompanying images. A copy of the written consent is available for review by the Editor-in-Chief of this journal.

\section{Competing interests}

The authors declare that they have no competing interests. 


\section{Author details}

${ }^{1}$ Department of Basic Medical Sciences, School of Medicine, University of Health and Allied Sciences, Ho, Volta Region, Ghana. ${ }^{2}$ Consultant Urologist, Department of Surgery, School of Medicine, University of Health and Allied Sciences, Ho, Volta Region, Ghana. ${ }^{3}$ Consultant Urologist, Department of Surgery, Korle Bu Teaching Hospital, Accra, Ghana. ${ }^{4}$ School of medicine and Dentistry, University of Ghana, College of Health Sciences, Accra, Ghana.

Received: 19 February 2021 Accepted: 18 May 2021

Published online: 12 July 2021

\section{References}

1. Indyk JA. Disorders/differences of sex development (DSDs) for primary care: the approach to the infant with ambiguous genitalia. Transl Pediatr. 2017;6(4):323.

2. Manzoor J, Aftab S, Yaqoob M. Ambiguous genitalia: an overview of 7 years experience at the Children's Hospital \& Institute of Child Health, Lahore, Pakistan. Pakistan J Med Sci. 2019;35(1):151.

3. Witchel SF. Disorders of sex development. Best Pract Res Clin Obstet Gynaecol. 2018;1(48):90-102.

4. Araujo-Melendez M, Verduzco-Aguirre H, Morales JJ, Martinez-Benitez B, Castillejos-Molina R, Fuentes A, Salama M, Bourlon MT. Disorders of sex development and malignant germ cell tumors. Oncology (Williston Park). 2020;34(10):421-6.

5. Estermann MA, Smith CA. Applying single-cell analysis to gonadogenesis and DSDs (Disorders/Differences of Sex Development). Int J Mol Sci. 2020;21(18):6614.

6. Kucukemre Aydin B, Saka N, Bas F, Kiray Bas E, Coban A, Yildirim S, Guran T, Darendeliler F. Frequency of ambiguous genitalia in 14,177 newborns in Turkey. J Endocr Soc. 2018;1:1185-95.
7. García-Acero M, Moreno O, Suárez F, Rojas A. Disorders of sexual development: current status and progress in the diagnostic approach. Cur Urol. 2019;13(4):169-78.

8. Öcal G, Berberoğlu M, Şiklar Z, Bilir P, Uslu R, Yağmurlu A, Tükün A, Akar N, Soygür T, Gültan S, Gedik VT. Disorders of sexual development: an overview of 18 years experience in the pediatric Endocrinology Department of Ankara University. J Pediatr Endocrinol Metab. 2010;23(11):1123-32

9. Kutney K, Konczal L, Kaminski B, Uli N. Challenges in the diagnosis and management of disorders of sex development. Birth Defects Res C Embryo Today. 2016;108(4):293-308.

10. Rey RA, Grinspon RP. Normal male sexual differentiation and aetiology of disorders of sex development. Best Pract Res Clin Endocrinol Metab. 2011;25(2):221-38.

11. Park SY, Jameson JL. Minireview: transcriptional regulation of gonadal development and differentiation. Endocrinology. 2005;146(3):1035-42.

12. Newman K, Randolph J, Anderson K. The surgical management of infants and children with ambiguous genitalia. Lessons learned from 25 years. Ann Surg. 1992;215(6):644.

13. Ahmed SF, Rodie M. Investigation and initial management of ambiguous genitalia. Best Pract Res Clin Endocrinol Metab. 2010;24(2):197-218.

14. Bougnères $P$, Bouvattier $C$, Cartigny M, Michala L. Deferring surgical treatment of ambiguous genitalia into adolescence in girls with 21-hydroxylase deficiency: a feasibility study. Int J Pediatr Endocrinol. $2017 ; 2017(1): 1-5$

\section{Publisher's Note}

Springer Nature remains neutral with regard to jurisdictional claims in published maps and institutional affiliations.
Ready to submit your research? Choose BMC and benefit from:

- fast, convenient online submission

- thorough peer review by experienced researchers in your field

- rapid publication on acceptance

- support for research data, including large and complex data types

- gold Open Access which fosters wider collaboration and increased citations

- maximum visibility for your research: over $100 \mathrm{M}$ website views per year

At BMC, research is always in progress.

Learn more biomedcentral.com/submissions 